\title{
worldview
}

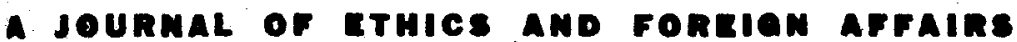

\section{RELIGION AND THE PRESENT TIME}

This is the season when we celebrate God's mighty acts. He delivered Israel from the bondage of Egypt; He delivered Jesus from the bondage of death. In the feasts of Passover and the Resurrection we know again each year that our God is not an abstraction. He is the living God whose providence is marked in human history and to whose justice all nations must finally bend. The Easter liturgy reminds us: "The earth trembles and is silent when God rises up in judgment."

The divine intervention in history is not a convenience, however. It is not automatic. God does not rush in, from day to day or from year to year, to rescue men from the consequences of their stupidity, arrogance and greed. God's justice is the ultimate justice; His victory is the ultimate victory. In the end, "all things will be well." But in the meantime, He has given the world to the management of men. And in managing the world, men cannot rely on miracles or grace. They must rely on their own resources of intelligence, imagination, and goodwill.

The world today offers little evidence that these resources will save us. Before the final triumph of God's justice, man's injustice may bring the world to ruin. The nations today are busily preparing a graveyard for the human race. The greatest achievements of modern science are directed toward death.

Everyone admits that a war fought with massive thermonuclear weapons would be a catastrophe too horrible to be imagined. But the powers of the world continue their preparations for thermonuclear war. They continue to talk, and to act, on the assumption that a new war is at least conceivable, as a last resort if all else fails. The world's reality thus seems to mock religious hope and to belie divine providence itself. Where is God in a world of thermonuclear arms? And what should be-what can be-the word of religion in such a world?

Mr. C. Wright Mills is convinced that for the present time religion has no word at all. Religion today, he thinks, is part of the general moral defeat of man. It is a mere yea-sayer to the "realistic" madness of the world. It is irrelevant, a "joke," an agent of conformity to the callousness of the age. To a generation hell-bent on nuclear suicide, it gives no warning. Mr. Mills believes that in the present situation "the decisive test of Christianity". is pacifism-"the witness of the refusal by individuals and by groups to engage in war." And today Christianity is failing this test.

Mr. Mills set forth these convictions in "A Pagan Sermon to the Christian Clergy," which was published last month in The Nation. Substantial excerpts from the "Sermon" are reprinted elsewhere in this issue of Worldolew. What Mr. Mills says is important. It is eloquent and it is moving. It should be widely read among men concerned for the role of religion in the present time. It raises the questions about its role, and in the process it scores some discomforting, even painful points. But in the end it rests on a profoundly uncritical illusion. It assumes that religion is something disembodied, that it can function in the world simply, without reference to the complexities that here and now exist.

Conformity, yea-saying, are; as Mr. Mills insists, temptations to which "religion" too readily succumbs. If "XYZ-ism" is proclaimed as an official national policy today, then, as he observes, a good deal of religious declaration is "XYZ-ist" tomorrow. Religion too often permits itself to be used as a guarantor of the status quo. Instead of proclaiming the disquieting truths that lie deep within it, it mouths the comfortable platitudes the world loves to hear. But to admit these things is not to define the role of religion in the present hour.

Religion, as religion, is concerned with truths that transcend each time and place and yet are valid for each time and place. Religion, as religion, witnesses to ultimate values. It tells us the 
tinal meaning of things. And in the telling it provides imperatives for the vocation of each religious man to work for the extension of God's justice in history.

But religion, as religion, does not, can not, tell the religious man how, in any given situation, justice can best be achieved. It does not provide a blueprint or a handbook of means. Here the religious man is at one with every other man in being forced to rely on his natural resources of intelligence and imagination. And here, like other men, he may fail through lack of information, or miscalculation, or sheer stupidity. But his failure then will not be a moral failure. It will be a failure in practical judgment.

Mr. Mills, it seems, confuses these two. Perhaps the ends of justice and peace can be achieved only through the absolute refusal by individuals and by groups to engage in war. Perhaps pacifism is the only "realism" today. Perhaps the idea of deterrence is folly and the testing of nuclear weapons will lead inevitably to their use. But these are not questions that morality can decide. They are political questions, questions of means, about which men equally moral, equally religious, may disagree. Mr. Mills' mistake, his temptation to a "pagan" hubris, perhaps, is to make "morality" somehow synonymous with his own political prejudices.

-

More immediately than at any other time in history, religion and morality demand that war be averted, that a retreat from the world's madness be made, that peace with justice be somehow secured. But when the man of religious conscience attempts to implement these demands he enters the area of politics. And the answers here are not as clearcut as Mr. Mills seems to think.

It is possible, for example, that a good many men (as strongly motivated morally as Mr. Mills could wish ) think that unilateral disarmament by the United States at this time would increase, rather than decrease, the threat of war, that it would quicken, rather than halt, the advance of injustice. Religion or morality as such cannot resolve these questions. What they demand is the effort to resolve them.

God works in history but $\mathrm{He}$ works through man. Religion does not provide a retreat from the complexities of the world; it provides the imperative for dealing with the world's complexities seriously. It guarantees an ultimate hope, but it leaves us with the burden of working out the world's problems, here and now, in relation to things as they are. "Morality" divorced from responsibility, from reality, and from humility is merely moralism.

\section{TORTURE IN ALGERIA}

Sometime during World War II Cyril Connelly wrote in Horizon that "we all have our fascist moments." The war in Algeria (whatever may be the other rights and wrongs of it) is proving that France, the country of light, has its fascist moments, too. Examples of French brutality in Algeria have united religious and humanist opinion in a horrified protest rarely achieved in that divided country.

There have been a long series of episodes. The most recent is one of the more dramatic. Henri Alleg, the former editor of the Communist paper Alger Republicain, wrote a book, La Question, which described, in nauseating detail, tortures to which he was subjected by French parachutists last summer. Excerpts from the book were published in France Observateur and the paper was promptly confiscated by the Paris police.

But Jean-Paul Sartre had read La Question and he wrote about it in another Paris journal, $L^{\prime} E x$ press. "Hitler," M. Sartre says he now realizes, "was only a forerunner." Fifteen years ago "Frenchmen were screaming in agony and pain," and, watching German soldiers walking about Paris, they wondered: "They look like us. How can they act as they do?" And "we were proud of ourselves for not understanding."

But today, M. Sartre says, "we know there was nothing to understand. The decline has been gradual and imperceptible. But now when we raise our heads and look into the mirror we see an unfamiliar and hideous reflection: ourselves."

The issue of L'Express containing M. Sartre's article was also promptly confiscated by the Paris police.

But mere confiscation cannot silence a civilized people's protest. The religious press, the French bishops, and distinguished religious laymen have joined in pointing to France's shame. No provocation can excuse the brutality, that has been too well documented during the Algerian war. This is not an "internal affair" of France. It involves the conscience of men everywhere, and everywhere the protest against such things must be made. 


\section{SINCERELY YOURS}

Many Americans must now be aware that during the past few months one of the most curious correspondences in world history has been carried on through the pages of the New Statesman, the British socialist weekly review. First Lord Bertrand Russell wrote an open letter to President Eisenhower and Mr. Khrushchev. In the name of humanity he pleaded with both leaders ("Most Potent Sirs," he addressed them) to reexamine their positions and make a last great effort to halt an arms race that threatens mankind with extinction.

To everyone's surprise, Mr. Khrushchev promptly replied to Lord Russell. His letter was a long one, but, in brief, it said: Dear Lord Russell, you're perfectly right, and the peace-loving Saviet Union would like nothing better than to stop the arms race. Just look at our record. But what can we do about the Americans? Just look at their record.

Several weeks later-and even more to everyone's surprise-Mr. John Foster Dulles ("at the request of President Eisenhower") replied, too. His letter was not nearly so long as Mr. Khrushchev's, but, in effect, it said: Dear Lord Russell, you're perfectly right, and the peace-loving United States would like nothing better than to stop the arms race. Just look at our record. But what can we do about the Russians? Just look at their record.

Now the exchange has (apparently) ended, with a final, exasperated word from Lord Russell. Both the replies, he notes, were "extraordinarily similar in tone . . . Both, in words, acknowledge that a nuclear war would defeat the purpose of both parties equally, but neither draws the moral that the acerbity of their disagreements must be lessened since this acerbity increases the likelihood of nuclear war."

And this seems to indicate something basically insane in the present stalemate.

\section{It the Magarines}

What to do about The Bomb seems to be the chief topic of discussion in the month's magazines. In Britain-where such figures as Bertrand Russell and J. B. Priestley are leading a highly vocal campaign for the abolition, not only of nuclear warfare, but of
Britain's current defense agreements with her allies, notably America-the debate is most intense. In the March 22 issue of The Ecompmist, this wave of protest is denounced as "the great confusion." "For peace's sake, let attention be paid first, at Oxford and elsewhere, to the basic fallacy of the assumption that the way to abolish nuclear war is for Britain to contract out of the alliance." The Economist challenges the agitators on a number of points-their unwillingness, for instance, to consider the likelihood that the size of the bomb itself would preclude its use except as a last resort growing from a military miscalculation. "What is needed, therefore, is not a pronouncement about abolishing the bomb (which, at least in war, would be impossible to enforce) but a policy to minimize the chance of such miscalculation." .

The Economist goes on to insist that, far from advancing the cause of a safe peace, the agitators have in effect imperilled it. They have reduced Macmillan, for one, to hollow threats, of retaliation; they have mitigated the chances for a "controlled disarmament" on all sides; they have encouraged the spread of an irresponsible "neutralism"; and, lastly, they have sadly misjudged the scope of Britain's moral influence. As to renouncing the Western alliance in the hope of "breaking the deadlock," The Economist maintains that "it is on this deadlock that the avoidance of war at present depends."

The author of Nuclear Weapons and.Foreign Policy, Henry A. Kissinger, $s$ ies in the Western alliance the means to a new \& rity. His solution, however, is radically opposed tu nat of the nuclear disarmers. Writing in the April issue of Foreign Affairs, he proposes "a viable NATO strategy" based on missile installations on the Continent. "Refusal to accept missiles will only increase Europe's dependence on the United States," Dr. Kissinger believes. "If the United States assumes the sole responsibility for the defense of the free world, it will also assume the responsibility for defining the carus belli." As a strategist, Dr. Kissinger sees a grave discrepancy between NATO's avowed policy of defense and its impotence in the field of action. "A local deterrent in Europe is required to increase the range of our options, and to bring the deterrent policy of NATO into line with the strategy it is prepared to implement. A strategy of local defense is essential not as a device to save the alliance-though it will serve this purpose; rather, the alliance alone offers the possibility of a strategy which does not inevitably involve catastrophe."

-What, then, as Dr. Kissinger asks himself, of disengagement in Europe? "Disengagement," he concludes, "invites a variety of new dangers while reducing the forces to meet them." PAMPHHus 